
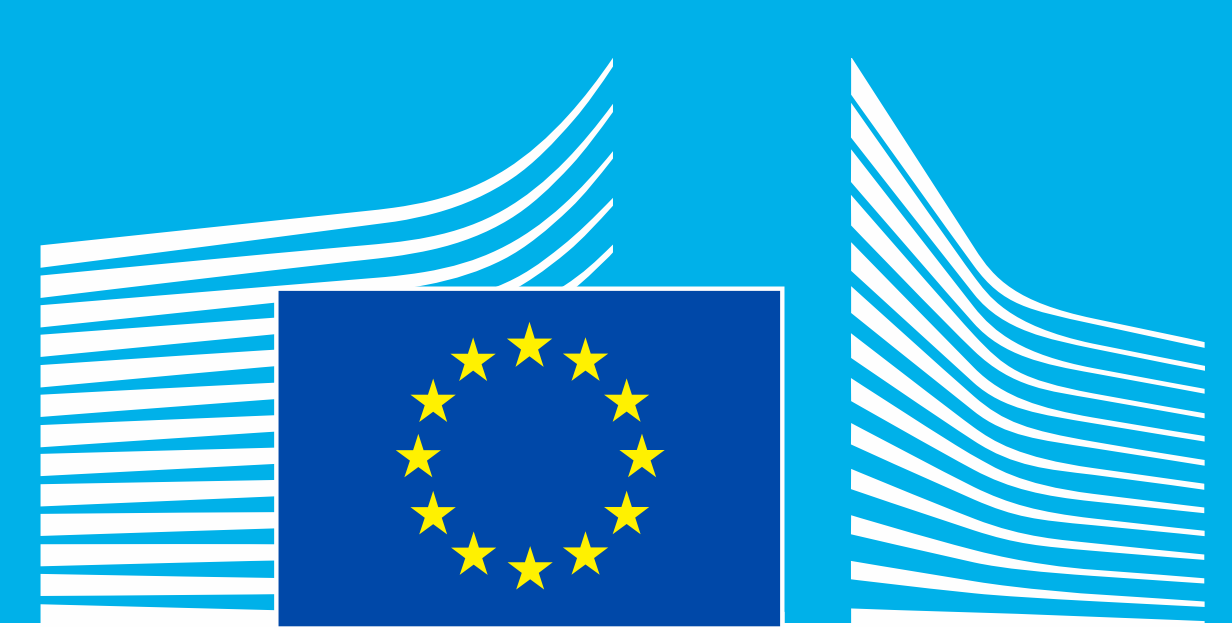

European

Commission

\title{
Improving access to finance for innovative firms with growth potential: evidence of impact of $R \& D$ grant schemes on firms' output
}

Testa, G. and Szkuta, K., European Commission DG JRC

\section{Motivation / Objectives}

High-growth firms are increasingly a target for government interventions (European Commission, 2016). This is especially true for Europe which lags behind the US in the number of fast growing highly innovative enterprises (so-called scale-ups). In response to this large scale-up gap, the current policy debate has focussed on new sources and forms of R\&I funding to enhance EU level support for scale-ups.

Objective: This paper examines the impact of R\&D grant schemes on young innovative companies with growth potential. It focuses on the output additionality, i.e. the effects of R\&D grants for scale-ups on the output of firms.

\section{Main Research Questions}

\section{Our main research questions are}

1. What are the effects of R\&D grants on scale-ups' output as measured by innovation activities, employment growth and firm performance (in terms of output, sales including sales of new products and foreign sales/exports - value added and revenues)?

2. How do these R\&D grants that specifically target young innovative firms with growth potential compare in term of employment, firm economic and innovative performance and innovative activities with generic R\&D grants and R\&D subsidies commonly used as external funding to support both SMEs and large enterprises?

\section{Methodology}

Our research approach draws on policy evaluation studies, and academic literature.

(a) Sample papers: selection criteria

- Direct R\&D grants were selected only if the scope was to help young innovative companies grow faster (e.g. promote growth and exports, increase the commercialisation of innovation, enhance competitiveness).

- Young $<=10$ years old

• Examples of keywords used were "R\&D" "grants", "SMEs", "young", "innovative firms", "high-growth firms", and "growth potential".

(b) Selection criteria for generic R\&D grants and R\&D subsidies

- Generic R\&D grants were defined as R\&D programmes grants targeting all companies (SMEs and larger enterprises) in all sectors.

- R\&D subsidies include all R\&D programmes (grants, loans and tax incentives), without distinguishing between instruments when reporting effects.

\section{Results}

The results on the effect of R\&D grants for innovative enterprises with growth potential shows:

- Impact on employment: The average number of employees ranges from 7 to 16 per granted firms.

- Impact on both sales' growth, and share of innovative sales:

Strong and positive effect on total sales, and share of innovative sales.

Time lag. Effects on sales' growth take from two to four years to appear.

Growth boosting effects. Firms continue to grow for several years following the

receipt of the subsidy (Autio and Ranniko, 2016; Soderblom et al., 2015). $\rightarrow$ Quality signal

- Impact on innovation: Strong and positive effect on patent

Table 1. Output Additionality

\begin{tabular}{|l|c|c|c|}
\hline Effects on: & $\begin{array}{c}\text { R\&D grants for scale- } \\
\text { ups }\end{array}$ & Generic R\&D grants & R\&D subsidies \\
\hline Employment & $\bullet \bullet \bullet$ & $\bullet \bullet \circ$ & $\bullet \circ \bigcirc$ \\
\hline $\begin{array}{l}\text { Firm innovative and } \\
\text { economic performance }\end{array}$ & $\bullet \bullet \bullet$ & $\bullet \bullet \bigcirc$ & $\bullet \bullet \bigcirc$ \\
\hline Innovation & $\bullet \bullet \bullet$ & $\bullet \circ \bigcirc$ & $\bullet \circ \bigcirc$ \\
\hline
\end{tabular}

$\bullet \bullet \bullet=$ major relevance, $\bullet \bullet \bigcirc=$ moderate relevance, $\bullet \bigcirc \bigcirc=$ minor relevance

The European Commission's science and knowledge service Joint Research Centre

EU Science Hub: ec.europa.euljirc @ @EU_ScienceHub in Joint Research Centre

f EU Science Hub - Joint Research Centre 罝 EU Science Hub
The results of the comparative analysis show:

- The effects for R\&D grants for young innovative firms are larger than the effects of generic $R \& D$ grants and $R \& D$ subsidies.

- For generic R\&D grants, the effects are higher when the grants induce changes in firm behaviour (collaboration and enhance firm human capital endowment) and when they target particular technologies or sectors (high-tech companies)

- The combination of R\&D grants and tax incentives is more effective in increasing firm innovation than using only one instrument.

Table 2. Evidence sources

\begin{tabular}{|l|c|c|c|}
\hline & All sources & Academic articles & Evaluation reports \\
\hline R\&D grants for scale-ups & 20 & 13 & 7 \\
\hline Employment & $\mathbf{1 1}$ & $\mathbf{5}$ & $\mathbf{6}$ \\
\hline $\begin{array}{l}\text { Economic and Innovation } \\
\text { performance }\end{array}$ & $\mathbf{1 4}$ & $\mathbf{8}$ & $\mathbf{6}$ \\
\hline Innovation & $\mathbf{7}$ & $\mathbf{3}$ & $\mathbf{4}$ \\
\hline
\end{tabular}

\section{Relevance for Policy}

- R\&D grants stimulate and prepare the companies for the growth phase.

- Targeted funding (technology focus) delivers better results for disruptive innovations, whereas generic grants for SMEs are better suited for knowledge diffusion as they mostly deliver new to the firm rather than new to the market results.

- Selection mechanisms built on milestones or subsequent phases of funding are still rarely used although their effects are very positive. This calls for a greater use of his type of mechanisms.

- The competitive and attractive R\&D grants help companies to attract follow up funding (signalling effect especially for equity).

- Financial measures coupled with complementary services (e.g. networking, advice) have a longer lasting effect.

- Tax incentives and grants are complementary as regards to their impact on firm's growth and innovation activities given the evidence of higher impact of combined application (tax incentives and grants).

Table 3. Summary of R\&D grants' design

\begin{tabular}{|c|c|c|}
\hline Description & Advantages & Challenges \\
\hline \multicolumn{3}{|c|}{ R\&D grants for scale-ups } \\
\hline $\begin{array}{l}\text { - Phased approach, often linked to } \\
\text { performance. } \\
\text { - Mostly delivered with additional services } \\
\text { (training, mentoring, advice). } \\
\text { - Small cohorts of firms. } \\
\text { - Eligibility criteria more detailed and } \\
\text { focused cf. generic grants (e.g. specific } \\
\text { sectors, project managers' experience, } \\
\text { company age). }\end{array}$ & $\begin{array}{l}\text { - Phased approach allows } \\
\text { distribution of funding based on } \\
\text { results - not project proposals } \\
\text { alone. } \\
\text { - Added-value services help } \\
\text { entrepreneurs to deliver project } \\
\text { to market. }\end{array}$ & $\begin{array}{l}\text { - Phased approach requires } \\
\text { clear milestones to enable } \\
\text { monitoring of the process. } \\
\text { - Problems with picking winners } \\
\text { if eligibility criteria very } \\
\text { stringent. }\end{array}$ \\
\hline \multicolumn{3}{|c|}{ Generic R\&D grants } \\
\hline $\begin{array}{l}\text { - Single grant. } \\
\text { - Financial suport rarely linked with } \\
\text { additional services. } \\
\text { - Larger cohorts of firms. } \\
\text { • Eligibility criteria more generic: R\&D } \\
\text { intensity, company's size, no age limits. }\end{array}$ & $\begin{array}{l}\text { - Simple administrative rules } \\
\text { - Risk more equally distributed } \\
\text { due to larger cohorts }\end{array}$ & $\begin{array}{l}\text { - Risk of funding mostly new-to- } \\
\text { the-firm innovation and/or } \\
\text { issues with commercialisation } \\
\text { given the lack of support } \\
\text { during project development }\end{array}$ \\
\hline
\end{tabular}

\section{Sources/References}

Acemoglu, D., U. Akcigit, N. Bloom, and W. Kerr (2013). Innovation, Reallocation and Growth, National Bureau of Durufle, G. T. Hellimann and K. Wilson (2017). From start-up to scale-up: examining public policies for the financing of high-growth ventures. Working Paper, 04, Bruegel. European Commission (2016), Europe's nex leaders: the Start-up and Scale-up Initiative, Communication from the Commission to the European Parliament, the Council, the European Economic and Social Committee and the Committee (n) Edler, J, P. Cunningham, A. Gok, and P. Shapira (2016). Handbook of Innovation Policy Impact, EE Edlgar.

Giuseppina Testa (giuseppina.testa@ec.europa.eu) Katarzyna Szkuta (katarzyna.szkuta@ec.europa.eu) 